\title{
The effect of crown pruning and induction of Acremonium sp. on agarwood formation in Gyrinops caudata in West Papua, Indonesia
}

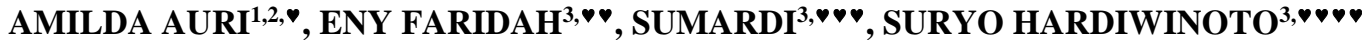 \\ ${ }^{1}$ Forestry Program, Graduate School, University Gadjah Mada. Jl. Agro No. 1, Bulaksumur, Sleman 55281, Yogyakarta, Indonesia \\ ${ }^{2}$ Department of Forestry, Faculty of Forestry, Universitas Papua. Jl. Gunung Salju, Amban, Manokwari 98314, West Papua, Indonesia. \\ •email: auriamilda@gmail.com \\ ${ }^{3}$ Faculty of Forestry, Universitas Gadjah Mada. Jl. Agro No.1 Bulaksumur, Sleman 55281, Yogyakarta, Indonesia. \\ Tel./fax.: +62-274-55541,vemail: enyfaridah@ugm.ac.id,vvsumardibdh@yahoo.com,•vvvsuryohardiwinoto@gmail.com
}

Manuscript received: 12 April 2021. Revision accepted: 8 June 2021.

\begin{abstract}
Auri A, Faridah E, Sumardi, Hardiwinoto S. 2021. The effect of crown pruning and induction of Acremonium sp. on agarwood formation in Gyrinops caudata in West Papua, Indonesia. Biodiversitas 22: 2604-2611. Agarwood-producing trees have been planted by the community, but have currently not produced agarwood resin. This research examines the crown pruning effect and fungi inoculation effectivity on the formation of agarwood resin in Gyrinops caudata. The environmental modification was also ascertained based on the real environmental situation in natural forests. Furthermore, it was assumed that environmental conditions significantly influenced the growth, G. caudata tree association, and fungi infection. This method involved the tree crown cover modification. Tree crown was categorized into three different classes, i.e. dense crown (no pruning); moderate (pruning 25\%), and sparse (pruning 50\%). The results showed that inoculating fungi of Acremonium sp. to infection coverage area after three months produced the best results, due to Fcount 79.671. However, crown prunings obtained through heavy, moderate and non-pruning did not show any effect on stem infection spread. In the sixth month, it was observed that the fungi inoculation factor of Acremonium sp. had a significant effect on infection spread formation by Fcount of 168.894. The change in wood internal tissue also had a highly significant effect as depicted by Fcount 461.516. The fragrance level treatment also showed a considerable effect with Fcount 290.385.
\end{abstract}

Keywords: Acremonium sp., agarwood, Gyrinops caudata, inoculation, pruning

\section{INTRODUCTION}

Agarwood is one of the non-timber forest products in form of blackish resin found within the trunk, branch and root, with a distinctive pleasant fragrance. This is a kind of wood in varied distinctive forms and colors which contain a certain fragrant resin level. Agarwood is derived from any tree or part of trees that produced agarwood resin naturally and died as a result of infection, natural or manmade causes (BSN 2011). Tree genera that produce agarwood include Aquilaria sp., Gonystylus sp., and Gyrinops sp. Taxonomically, these genera are under Thymelaeaceae family (Naef 2011; Rindyastuti et al. 2019; Batubara et al. 2020).

The high demand for agarwood worldwide has caused a rise in the selling price of agarwood resin. The superior resin can be valued at up to US\$ 100,000/kg (Cui et al. 2013). The common practice of extracting this resinous wood is derived from the wild harvest of natural forests (Thanh et al. 2015). To ensure the sustainability of agarwood-producing plants, Aquilaria spp. and Gyrinops spp. have been listed on Appendix II on Convention on International Trade in Endangered Species of Wild Fauna and Flora (CITES) (Wong et al. 2015). In recent years, there has also been special concern on planting forests designed specifically for agarwood-producing plants (Nor et al. 2015). Furthermore, initiatives on its cultivation, including artificial induction engineering will constitute one of the best practices which ensure the sustainability of agarwood-produced plants.

Gyrinops caudata is one of the agarwood-producing trees grown in Papua. Its distribution covers Agats, Mappi, Boven Digoel, Merauke, Manokwari dan Teluk Bintuni (Auri 2012). Ecologically, Gyrinops caudata grows in primary forest in swampy areas, which range between 2 to $20 \mathrm{~m}$ asl. For example in Sago Palm forests, the typical soil is sandy-clay and loam (Mulyaningsih dan Yamada 2007). Therefore, there are potentials in the cultivation of this plant, especially in various forest plantations in Papua.

Many research has been conducted to determine the appropriate method for improving the quality and quantity of agarwood resin. Some studies utilized fungal Acremonium sp. engineering for agarwood formation, including double agarwood induction by applying Acremonium sp. and Fusarium sp. to accelerate its formation in Aquilaria microcarpa (Wulandari 2009). Another study involved the combination of different chemical compounds with Acremonium sp. to enhance the formation of agarwood compounds (Murtaip 2010). Other factors such as tree age, tree species difference, seasonal influence, environmental and genetic variations also play important roles in the formation of agarwood resin (Novriyanti 2008; Matatula 2019). Furthermore, Isnaini (2003) stated that there is also a biotic factor (fungal) that affects the speed of the formation of agarwood resin. Pathogenic fungal interaction causes a physiological 
change in plants which leads to visual changes on its cell, tissue, or organ. In the interaction process between the fungi and its host, fungal pathogenesis is the most important factor. This is observed on the wounded internal wood tissue which causes a physiological change in its living parenchyma cells. This is also marked by an extensive spread of wood infection as the initial symptom of biotic and abiotic agent attack (Winarsih 2014). The physiological changes include leaf chlorosis, wood discoloration around the infected area, and the presence of pleasant fragrance as well as the accumulation of terpenoid compounds in the inoculated area (Nobuchi and Siripatanadilok 1991; Pojanagaroon and Kaewrak 2002; Putri et al. 2008).

In recent years, some communities planted agarwoodproducing trees. However, these trees have not produced agarwood resin. This necessitates research on the effectiveness of fungal inoculation of Acremonium sp. and environmental stress on agarwood formation in Gyrinops caudata.

\section{MATERIALS AND METHODS}

\section{Study area}

This research was conducted in several places which include the Agarwood Plantation Forest of Teluk Bintuni District, West Papua Province, Indonesia. The Gyrinops caudata plantation is located at the position of $133^{\circ} 36^{\prime} 14.28^{\prime \prime} E-2^{\circ} 6$ '2.72'S. Furthermore, the map of the research location is shown in Figure 1. The development of Acremonium sp. was conducted in the silviculture Laboratory, University of Papua. This research duration spanned 9 months from December 2018 to August 2019.

Gyrinops caudata were cultivated in the research forest in 2005 and this covers five hectares in certain planting spacing $2 \mathrm{~m} \mathrm{x} 3 \mathrm{~m}$. This G. caudata forest is located 100 meters above sea level. It has sand, clay and loam with $\mathrm{pH}$ 7. G. caudata trees in the forest come from two sources; nursery seedling and wild seedling from the nearest area in Teluk Bintuni District. Furthermore, the forest is surrounded by agricultural areas belonging to local farmers from nearby regions.

This research examined environmental modifications based on the environmental condition of the Gyrinops caudata in a natural forest. An observation in three natural forests of G. caudata (Manokwari, Teluk Wondama, and Teluk Bintuni) had a light intensity of $56-75 \%$. Furthermore, the plantation has never been thinned, and the initial measurement of light intensity before pruning was $70-85 \%$. It is also believed that light intensity influences the fungal interaction infecting $G$. caudata trees during agarwood formation. Therefore, pruning is necessary for the entry of light. This class of canopy cover was divided into three classes, i.e., dense cover (pruning 0\%), moderate crown cover (pruning 25\%), and sparse crown cover (pruning 50\%).

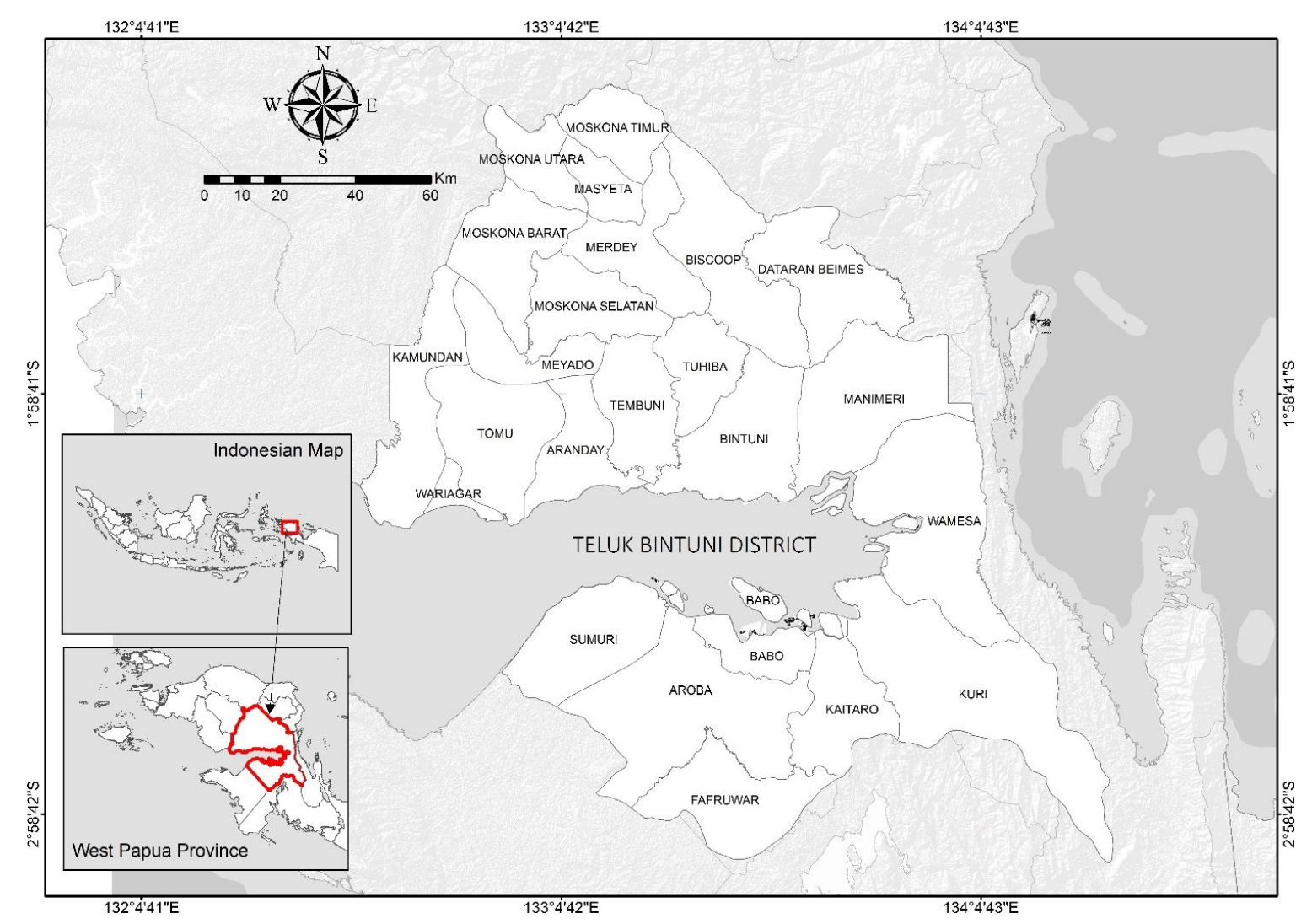

Figure 1. Map showing Gyrinops caudata plantation area of Teluk Bintuni District, West Papua, Indonesia 
Trees used for sampling were Gyrinops caudata trees with a diameter $\geq 8 \mathrm{~cm}$. There were three sites tested that were dependent on the crown cover. The pruning levels conducted were of three types; $0 \%, 25 \%$ and pruning $50 \%$.and was carried out seven days before inoculation. This began by drilling or using a wounded tree for infection. Afterward, the Acremonium sp. inoculum was applied to this wound in order to accelerate agarwood formation. The inoculated hole was drilled according to specific requirements (diameter $0.8-1 \mathrm{~cm}$ ) in 1/3-1/2 depth from tree diameter, with a distance $10 \mathrm{~cm}$ above the ground. The treatment used the fungal-induction method with a spacing $10 \times 5 \mathrm{~cm} 2$ in each section. Each tree had 30 drilling holes, while each treatment had five (5) times repetition per tree. Furthermore, each tree was tested for one treatment only. The trees used in this research had 5 repetitions x 3 pruning levels $\mathrm{x} 2$ treatments (Acremonium inoculation and control), i.e., 30 trees.

The fungi applied in this research were derived from the natural forest of Teluk Bintuni District. They were purified and grown on PDA (Potato Dextrose Agar) media in Silviculture Laboratory, Faculty of Forestry UNIPA. Afterward, it was sent for identification to the Pests and Disease Plant Laboratory of Faculty of Agriculture UNIPA. The results showed that the pure-culture strain was Acremonium sp. The next step involved the transfer of pure-culture fungi into the mixed formula media $\left(10^{4} / \mathrm{g}\right)+$ rice powder $(5 \mathrm{~g})+$ glucose $(10 \mathrm{~g})+$ potex $(100 \mathrm{~mL})$ (Thanh et al. 2015).

In this research, the variables examined include expansion and spread type, wood internal tissue discoloration, the fragrance content, and external environmental factors. The measurement of expansion and spread type was conducted by measuring the area coverage infection $\left(\mathrm{cm}^{2}\right)$ surrounding the drill holes monthly. The bark around the drill holes was peeled and the infected area was measured using trac paper. Meanwhile, the measurement of spread data derived from tracing paper was converted into millimeter blocks in order to determine the coverage in centimeter square values $\left(\mathrm{cm}^{2}\right)$ (Rahayu 2009). The wood discoloration was measured and observed in levels based on the score system by utilizing Rahayu et al. (2009) method where color modification on Munsell Soil Color Chart (10Y) $(0$ = Very pale brown (8/3)), $1=$ light yellowish-brown (6/4), 2 = dark yellowish-brown (4/4), $3=$ very dark grayish brown (3/2). This was expressed in the mean score values from three respondents. The respondents were gaharu seekers which usually collect agarwood from natural forests.

The bark surrounding the drill hole was peeled and grounded to determine the stem color. The observation on wood fragrance includes the aromatic level of agarwood compound generated around the drill hole. This was conducted every 3 months alongside an observation of wood discoloration. This observation was made on each hole and is set by utilizing an organoleptic test/ olfactory test using the mean score from three (3) respondents. The scale began from 0 to $3 ; 0=$ no fragrance; $1=$ least intense fragrance, 2 = fragrant, and $3=$ very intense fragrance (Rahayu et al. 2009).

\section{Data analysis}

The quantitative data were analyzed using the Split Plot Design. The first factor was the level of pruning as there are three pruning levels i.e. $50 \%, 25 \%$, and $0 \%$. The second factor was the inoculation treatment (Acremonium sp. and control). Furthermore, the Duncan Test was applied as a follow-up while statistical analysis was performed using the SPSS20 software. In general, the linear model of Split Plot Design can be viewed as follow:

$Y i j=\mu+\alpha i+\partial i k+\beta j+(\alpha \beta) i j+\varepsilon i j k$

Note:

Yij : Observed values of factor A level to-i, factor B level to-j, and repeated to-k

$\mu \quad$ : Mean of Response

ai : Fixed effect of Factor A

$\beta \mathrm{j} \quad$ : Fixed effect of Factor B

$(\alpha \beta)$ ij: (Fixed) Interaction of Factor A and B

Oik : Random component of normal whole-plot

eijk : Random effect of normal split-plot

\section{RESULTS AND DISCUSSION}

\section{Infection spread}

Crown pruning is well-known since the past as one of the engineering methods for plant growth. Pruning treatment and inoculating fungi Acremonium sp. are the basis of environmental manipulation in order to facilitate the formation of agarwood resin. The observation and analysis of variance after three months on the spread of infection combined with pruning treatment and inoculating Acremonium sp. are shown in Table 1.

Table 1. Analysis of variance of infection spread after 3 months

\begin{tabular}{|c|c|c|c|c|c|c|}
\hline \multirow{2}{*}{ Source of variance } & \multirow{2}{*}{ df } & \multirow{2}{*}{ Sum of squares } & \multirow{2}{*}{ Mean squares } & \multirow{2}{*}{ F count $_{1}$} & \multicolumn{2}{|c|}{$\mathbf{F}_{\text {table }}$} \\
\hline & & & & & 0.05 & 0.01 \\
\hline Corrected model & 5 & 23.086 & 4.617 & 17.011 & 2.62 & 3.90 \\
\hline Pruning & 2 & 0.731 & 0.365 & 1.346 & 3.40 & 5.61 \\
\hline Inoculum Acremonium sp. & 1 & 21.624 & 21.624 & 79.671 & 4.26 & 7.82 \\
\hline Pruning * inoculating Acremonium sp. & 2 & 0.731 & 0.365 & 1.346 & 3.40 & 5.61 \\
\hline Error & 24 & 6.514 & 0.271 & & & \\
\hline Total & 30 & 29.600 & & & & \\
\hline
\end{tabular}

Note: $\alpha=0.05$ 
Table 2. Analysis of variance on infection spread after 6 months

\begin{tabular}{|c|c|c|c|c|c|c|}
\hline \multirow{2}{*}{ Source of variance } & \multirow{2}{*}{ df } & \multirow{2}{*}{ Sum of squares } & \multirow{2}{*}{ Mean squares } & \multirow{2}{*}{ F count $_{1}$} & \multicolumn{2}{|c|}{$\mathbf{F}_{\text {table }}$} \\
\hline & & & & & 0.05 & $\mathbf{0 . 0 1}$ \\
\hline Corrected model & 5 & 253.139 & 50.628 & 35.909 & 2.62 & 3.90 \\
\hline Pruning & 2 & 7.509 & 3.755 & 2.663 & 3.40 & 5.61 \\
\hline Inoculum Acremonium sp. & 1 & 238.121 & 238.121 & 168.894 & 4.26 & 7.82 \\
\hline Pruning * inoculating Acremonium sp. & 2 & 7.509 & 3.755 & 2.665 & 3.40 & 5.61 \\
\hline Error & 24 & 33.837 & 1.41 & & & \\
\hline Total & 30 & 286.976 & & & & \\
\hline
\end{tabular}

Note: $\alpha=0.05$

The analysis of variance on infection spread after three months showed that crown pruning does not solely contribute to the values of $F_{\text {count }}$ which is 1.346 and $F_{\text {table }}$ 3.40 in the rate $\alpha=0.05$. Crown pruning applied through various methods i.e. heavy $(50 \%)$, moderate pruning $(25 \%)$ and non-pruning did not contribute to stem infection expansion. Furthermore, the analysis of variance on Acremonium sp. fungi inoculation of infection spread had a significant effect. This effect, after three months, showed certain values in which $F_{\text {count }}$ is 79.671 and $F_{\text {table }}$ is 4.26 in the rate of $\alpha=0.05$. Acremonium sp. infection of agarwood plant Gyrinops caudata stimulates wood discoloration due to the presence of terpenoid compounds as the indicator of the effectiveness and interaction between microbe(s) and agarwood plant. However, the analysis of variance on the interactional correlation between crown pruning factor and inoculation showed a less significant effect as the values of $F_{\text {count }}$ is 1.346 and $F_{\text {table }}$ is 3.40. These low values were obtained because the pruning factor did not influence the spread of infection after three months. The follow-up test on infection spread using the Duncan Test showed that pruning $25 \%$ had a greater value (1.053) followed by $50 \%$ $(0.82)$, while non-pruning had the smallest value $(0,674)$ at $\alpha=0.05$. These results signify that the three pruning types are in the same subset, and do not contribute difference for non-pruning $(0 \%)$, moderate $(25 \%)$, or heavy pruning $(50 \%)$.

Furthermore, six months post-inoculation, there was wood discoloration from very pale brown to dark yellowish-brown until very dark grayish brown. The analysis of variance on infection spread combined with pruning treatment and inoculation after six months is shown in Table 2.

From the analysis of variance on the infection spread parameter, the application of fungi inoculum was observed to increase the infection coverage. The treatment obtained different significant effects at $\alpha=0.05$, where the value of $F_{\text {count }}$ is 168.894 and $F_{\text {table }}$ is 4.26. Furthermore, the discoloration caused by wounds or the infection of Acremonium sp. on the sixth month generated a distinctive smell in comparison to non-discolored trees. In the three months post-inoculation, there was an extended spread of infection with a relatively similar average pace. Meanwhile, a significant infection spread was observed on the sixth-month post-inoculation. In terms of interaction between pruning and inoculating fungi, there was no significant change in values. This is depicted by $\mathrm{F}_{\text {count }}=$ 2.665 and $F_{\text {table }}=3.40$ where the significant effect $\alpha=0.05$. The factor of Acremonium sp. fungi inoculation immensely influenced infection spread. This fungal-triggered infection created certain blockades on plant distribution which caused the plant to synthesize phytalyosin compound as the tissue resistant reaction. This compound acts as a defense against disease and pathogens (Sumarna 2002). The results of Duncan test follow-up on infection spread at the six months showed that pruning $25 \%$ was better than nonpruning (2.725). However, pruning $50 \%$ had the smallest value (2.256) infection spread value compared to other pruning. This showed that the infection spread was higher when Acremonium sp. inoculation was performed on trees that receive pruning $25 \%$ and non-pruning $0 \%$, compared to pruning $50 \%$. The infection spread in the tissue is shown in Figure 2.

Agarwood tree puts in great effort to overcome the effect of crown pruning and the applied inoculation by initiating secondary metabolism to produce fragrant metabolites. In the sixth month of observation, the fungal isolate was presumed to have adapted considerably. This was more effective for infection spread into tissues. Therefore, the basis is that the longer the infection lasts, the better the agarwood resin will be.

Generally, a lot of synthesis of secondary metabolites is observed when plants respond to pathogen attack or survive under stress which is caused by biotic or abiotic factors. (Lambert et al. 2011; Faizal et al. 2016). This also occurs on trees that produce agarwood as a secondary metabolite called phytoalexins. Meanwhile, the sesquiterpene compound generated in agarwood plants occurs due to plant stress (Kumeta and Ito 2010). It is believed that the agarwood resin is formed when the stem or branch has been wounded or experienced microbial infection (Liu et al. 2015).

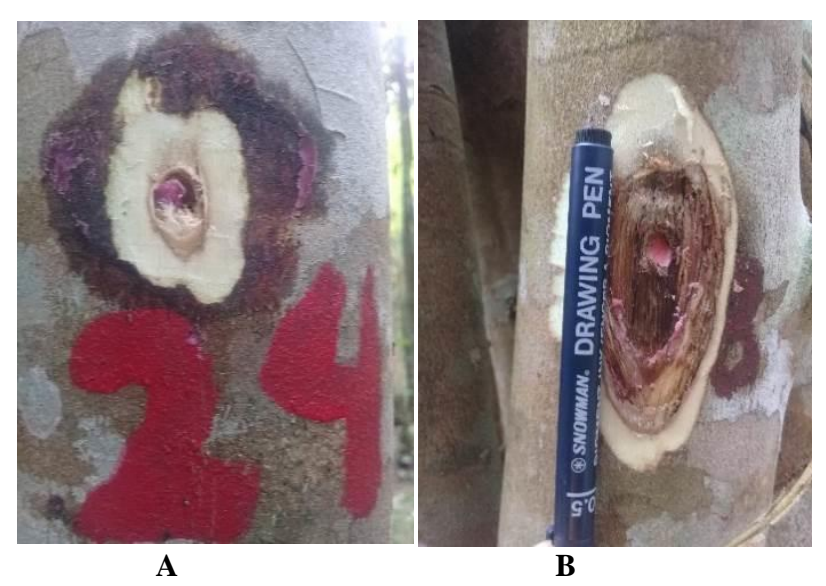

Figure 2. Observed infection spread: A. Three months, B. Six months 
Inoculating on $G$. caudata stems showed the initial response: wood discoloration i.e. from white to yellowishbrown in the area surrounding inoculating location in early weeks of treatment. Furthermore, Acremonium sp. is a fungus that induces the formation of agarwood compound on $G$. caudata tree. The infection caused by fungi Acremonium sp. occurs in the xylem and this decreases the cells and tissue performance of physiological functions. This decrease in physiological functions hinders plant growth which may lead to death. The infection caused by the fungi may also hinder photosynthesis in many ways, leading to chlorosis on leaves, necrosis on the infected area, and the decrease of photosynthesis products (Agrios 2005). Pruning crown treatment and fungi inoculation significantly changes wood discoloration to light brown, then blackish brown to black, around drilling holes in varied invasion levels.

\section{Colors of stem tissues}

The fungi effectivity was determined based on infection measurement on the tree applied. This measurement covered the length and width of the wood discoloration zone as well as color grades. To determine wood colors, the score system was used. Wood discoloration noticeably appeared on the third month after inoculation until the sixth month. In general, all treatments caused wood discoloration. The results and the analysis of variance on discoloration are shown in Table 3.

According to Table 3 , the pruning values had a significant effect on wood tissue discoloration with $\mathrm{F}_{\text {count }}$ value 10.020 and $F_{\text {table }}=3.40$ in the rate $\alpha=0.05$. Pruning treatment and the inoculation of Acremonium sp. on Agarwood tree affected wood discoloration from very pale brown to light yellowish-brown, dark yellowish-brown and very dark grayish brown. Based on observations, wood discoloration was darker in the non-crown pruning $(0 \%)$ and the moderate treatments $(25 \%)$ combined with inoculation of Acremonium sp. This discoloration is associated with the relative concentration level of agarwood resin-induced compounds produced by agarwood trees. $\mathrm{Ng}$ et al. (1997) and Barden et al. (2000) stated that a presumably darker discoloration is the result of an increased terpenoid compound accumulation caused by a fungal infection. The darker the color of the infected area, the higher the agarwood resin will be produced.

The interactional correlation between pruning treatment and fungi inoculation had a significant effect on wood tissue discoloration with $\mathrm{F}_{\text {count }}$ value 10.020 and $\mathrm{F}_{\text {table }}=$ 3.40. Duncan's follow-up test ascertained that $50 \%$ pruning treatment and $25 \%$, which had similar changes i.e. 1.011 and 1.069 respectively with significance value 0.321 . Meanwhile, non-pruning (0\%) significantly improved values i.e. the mean change was 1.2560 with significance value of 1.000 and standard error 0.057 . The crown leaves play an important role in plants by the production of photosynthate which enhances plant growth and development. Crown pruning presumably works as a deterrent for plant growth due to the effect of leaf volume decline. Leaves structures are critical in assimilate production, and support new shoots that require assimilation. Therefore, crown pruning may act as a hindrance to plant growth. Pruning leads to a more open crown in agarwood tree, thereby enhancing sunlight penetration and creating better airflow. This hinders the formation of agarwood resin. An extensively open tree crown decreases humidity around trees, and reduces the fungal attack rate.

Agarwood resin formation on wounded G. caudata of inoculated wood is visible in the dark brown areas or discoloration zones. The wood discoloration is related to fungal infection on wood tissues. Walker et al. (1997) stated that discoloration to brown is caused either by wounding, fungal attack, or chemical compound used. Furthermore, discoloration zones are not found on healthy wood (Faizal et al. 2016). This research showed that wood tissues with darker discoloration occurred due to the resin accumulation in agarwood trees. In the sixth month after pruning and inoculating fungi, infection growth increased significantly, which produced larger infection areas. Therefore, it was deduced that the more the infection lasts, the better the result will be. Brownish stem tissues surrounded by drill holes showed that there was a secondary metabolite accumulation as a response to pruning, wounding, and fungal infection. Agarwood resin produced by Gyrinops sp. developed a type of modification that serves as a barrier for fungal infection. Meanwhile, Aquilaria microcarpa also had resin in its wood tissues, specifically its phloem (Siburian et al. 2013). Resin accumulation formation in the xylem does not occur in healthy trees (Rao and Dayal 1992).

\section{Fragrance}

The interaction between pruning treatment and fungi inoculation had a significant effect on fragrance production level at $\alpha=0.05$ in the analysis of variance. Wood discoloration occurred in infected areas which caused fragrance production, and can only be smelled on the discolored stems. The determination of the fragrance level was carried out using the scoring system. Fragrance levels can be detected from the third month after inoculation until the sixth month. In general, all treatments caused the production of fragrance. The results and analysis of variance are shown in Table 4.

Table 4. shows that there was an interaction between pruning and application of treatment which had a significant difference value, where $\mathrm{F}_{\mathrm{Count}}$ was 13.889 and $F_{\text {table was }}$ 3.40. This illustrates that there was a real effect of pruning treatment and inoculating fungi on the aromatic fragrance. Furthermore, the presence of Acremonium sp. triggered the agarwood tree into a physiological defense mechanism by forming secondary metabolites with a pleasant fragrance. This fragrance only exists in trees with fungal interaction and was therefore absent in the control tree. Duncan Test showed that heavy pruning treatment $(50 \%)$ and moderate pruning $(25 \%)$ on average produced the same pleasant fragrance 1.0300 and 1.0530 respectively, with a difference of 0.764 . Meanwhile, nonpruning $(0 \%)$ contributed a value of 1.2560 where the significant value was 1.000 and standard error 0.076 . Without pruning, old branches will keep growing and hinder the more productive young branches. This leads to an increased humidity as well as fungal and pest attacks. 
Table 3. Analysis of variance on wood tissue discoloration

\begin{tabular}{|c|c|c|c|c|c|c|}
\hline \multirow[b]{2}{*}{ Source of variance } & \multirow[b]{2}{*}{ df } & \multirow[b]{2}{*}{ Sum of squares } & \multirow[b]{2}{*}{ Mean squares } & \multirow[b]{2}{*}{$\mathbf{F}_{\text {count }}$} & \multicolumn{2}{|c|}{$F_{\text {table }}$} \\
\hline & & & & & 0.05 & 0.01 \\
\hline Corrected model & 5 & 75.752 & 7.550 & 461.516 & 2.62 & 3.90 \\
\hline Pruning & 2 & 0.328 & 0.164 & 10.020 & 3.40 & 5.61 \\
\hline Inoculum Acremonium sp. & 1 & 37.096 & 37.096 & 2267.501 & 4.26 & 7.82 \\
\hline Pruning * inoculating Acremonium sp. & 2 & 0.328 & 0.164 & 10.020 & 3.40 & 5.61 \\
\hline Error & 24 & 0.393 & & & & \\
\hline Total & 30 & 38.145 & & & & \\
\hline
\end{tabular}

Note: $\alpha=0.05$

Table 4. Fragrance levels analysis of variance

\begin{tabular}{|c|c|c|c|c|c|c|}
\hline \multirow{2}{*}{ Source of variance } & \multirow{2}{*}{ df } & \multirow{2}{*}{ Sum of squares } & \multirow{2}{*}{ Mean squares } & \multirow{2}{*}{$F_{\text {count }}$} & \multicolumn{2}{|c|}{$\mathbf{F}_{\text {table }}$} \\
\hline & & & & & 0.05 & 0.01 \\
\hline Corrected model & 5 & 41.733 & 8.347 & 290.385 & 2.62 & 3.90 \\
\hline Pruning & 2 & 0.798 & 0.399 & 13.889 & 3.40 & 5.61 \\
\hline Inoculum Acremonium sp. & 1 & 40.136 & 40.136 & 1390.370 & 4.26 & 7.82 \\
\hline Pruning * inoculating Acremonium sp. & 2 & 0.789 & 0.399 & 13.889 & 3.40 & 5.61 \\
\hline Error & 24 & 80,559 & 0.29 & & & \\
\hline Total & 30 & 42.423 & & & & \\
\hline
\end{tabular}

Note: $\alpha=0.05$

The treatment administered on the tree wound, fungal infection, and the artificial introduction of chemical compounds may trigger pleasant aroma formation in sesquiterpene agarwood trees (Azzarina et al. 2016). This pleasant aroma also occurs in fungi Acremonium sp. inoculation in wood tissues. Acremonium sp. present in agarwood plant tissue causes the tree to produce brownish fragrant resin compounds as a response to pathogen attack (Bhuiyan et al. 2009) ( $\mathrm{Ng}$ et al. 1997). The main compounds of agarwood resin is sesquiterpenoid (a kind of terpenoid) and a strain of phenylethyl chromone. Both compounds play their roles in generating the distinctive pleasant fragrance of agarwood. Furthermore, different compounds of sesquiterpenoids and phenylethyl chromone have been isolated from different kinds of agarwood trees. The sesquiterpene group includes the strain of guia dienal, selina-dienone, and selina dienot, isopronoid, a-guaiene, ahumulene, and d-guaiene (Ishihara et al. 1991; Qi 1995; Ito et al. 2005; Bhuiyan et al. 2009; Okudera and Ito 2009). Meanwhile, phenylethyl chromone group includes 6,7dimethoxy-2- (2-phenylethyl chrome, dan 6-methoxy-2- [2(4-methoxyphenyl) ethyl] chromone (Qi 1995; Konishi et al. 2002; Qi et al. 2005; Dai et al. 2009; Okudera and Ito 2009).

Pruning is essential for maintaining the productivity and continuity of agarwood plant cultivation. However, in terms of production scale, it is necessary to consider the process of agarwood resin formation especially for its quality and quantity relating to color and fragrance. This is because pruning enhances healthier plant growth in optimum states with relative resistance to fungal attacks and insects. In the concept of agarwood resin formation and the integration of plant disturbing organism control, pruning serves as one of the technical culture acts that aim to cut the life cycle of main pests in agarwood plants.

In conclusion, the pruning treatment and inoculation of fungi Acremonium sp. in agarwood resin formation produced varied responses. In the third month of inoculating stem tissues, there was a brownish color around the drilling holes which occurred due to secondary metabolic accumulation. The discoloration caused by the wounding or infection of Acremonium sp. in the sixth month produced a different smell in comparison to nondiscolored trees. Furthermore, the sight of discoloration was significantly visible in the third-month postinoculation until the sixth month. All treatments affected wood discoloration, and the pruning treatment and inoculation of Acremonium sp. on agarwood trees influenced the wood discoloration in varied colors i.e. white, whitish yellowish-brown, to blackish brown. Wood discoloration was darker in the non-pruning treatment $(0 \%)$ and moderate pruning $(25 \%)$ alongside the fungi application of Acremonium sp. inoculum. Pruning influences agarwood tree crown to be more open, thereby causing more sunlight penetration and airflow which hampers the process of agarwood formation. A more open tree crown decreases the humidity around trees as well as reduces the fungal infection rate. Aromatic fragrance is only smelled in stems with discoloration. Furthermore, the presence of Acremonium sp. on agarwood trees triggers the tree's physiological defense response by forming pleasant aromatic secondary metabolites. This research suggests that there is a need for further studies related to agarwood formation mechanism through Acremonium sp. induction on different scales i.e. tissues and cells of agarwood plants. 


\section{ACKNOWLEDGEMENTS}

The author expresses gratitude to the Faculty of Forestry, Gadjah Mada University; LPDP (Indonesian Government Scholarship Institution) that funded this research. The author is also grateful to the local Forestry Department in Teluk Bintuni District which supported the conduction of this research in designed areas of Agarwood Plantation Forest. Lastly, the author appreciates any parties who helped to finish this article.

\section{REFERENCES}

Agrios G. N. 2005. Plant Pathology. 5th ed. Elsevier Academic Press, Nederland.

Auri A. 2012. Serangan hama penggerek batang sebagai indikator pembentukkan gubal gaharu pada pohon Gyrinops verstegii di Kampung Susweni. [Thesis]. Universitas Gadjah Mada, Yogyakarta. [Indonesian]

Azzarina AB, Mohamed R, Lee SY, Nazre M. 2016. Temporal and spatia expression of terpene synthase genes associated with agarwood formation in Aquilaria malaccensis Lam. N Z J For Sci 46 (1): 1-13 DOI:10.1186/s40490-016-0068-9.

Badan Standardisasi Nasional. 2011. Standar Nasional Indonesia. Gaharu. SNI 7631:2011. Jakarta. [Indonesian]

Barden A, Anak NA, Mulliken T, Song M. 2000. Heart of the matter: agarwood use and trade and CITES implementation for Aquilaria malaccensis. Traffic International, Cambridge, UK.

Batubara R, Hanum Ti, Handika A, Affandi O. 2020. The screening of phytochemical and antioxidant activity of agarwood le (Aquilaria malaccensis) from two sites in North Sumatera, Indonesia. Biodiversitas 4: 1588-1596. DOI:10.13057/biodiv/d210440.

Bhuiyan NI, Jaripa B, Nurul HB. 2009. Analysis of essential oil of eaglewood tree (Aquilaria agalocha Roxb) by gas chromatographymass spectrometry. J Bangl Pharm Soc 4: 24-28. DOI: 10.3329/bjp.v4i1.851.

Cui J, Guo S, Fu S, Xiao P, Wang M. 2013. Effects of inoculating fung on agilawood formation in Aquilaria sinensis. Chin Sci Bull 58 (26) 3280-3287. DOI: 10.1007/s11434-013-5856-5.

Dai HF, Liu J, Zeng YB, Han Z, Wang H, Mei WL. 2009. A new 2-(2Phenylethyl) chromone from chinese eaglewood. Molecules 14: 51655168. DOI: $10.3390 /$ molecules14125165.

Faizal A, Esyanti RR, Aulianisa EN, Santoso E, Turjaman M. 2016 Formation of agarwood from Aquilaria malaccensis in response to inoculation of local strains of Fusarium solani. Tress 31: 189-197. DOI: $10.1007 / \mathrm{s} 00468-016-1471-9$.

Ishihara M, Tomoyuki T, Tsuneya, Kenji U. 1991. Fragrant sesquiterpenes from agarwood. Phytochem 33: 1147-1155. DOI: 10.1016/0031-9422(93)85039-T.

Isnaini Y. 2003. Respon tunas gaharu (Aquilaria crassna dan A. filaria) terhadap inokulasi acremonium pada tiga konsentrasi medium kultur. Congress XVII and Indonesian Scholar Association Seminar, Bandung, 6-8 Agustus 2003. [Indonesian]

Ito M, Okimoto KI, Yagura T, Honda G, Kiuchi F, Shimada Y. 2005. Induction of sesquiterpenoid production by methyl jasmonate in Aquilaria sinensis cell suspension culture. J Essent Oil Res 17 (2) 175-180.

Konishi T, Konoshima T, Yasuo S, Shiu K. 2002. Six new 2-(2phenylethyl) chromones from Agarwood. Chem Pharm Bull 50: 419422. DOI: $10.1248 / \mathrm{cpb} .50 .419$.

Kumeta Y, Ito M. 2010. Characterization of $\partial$-guaiene synthases from cultured cells of Aquilaria, responsible for the formation of sesquiterpenes in agarwood. Plant Physiol 154: 1998-2007. DOI: 10.1104/pp.110.161828.

Lambert E, Faizal A, Geelen D. 2011. Modulation of triterpene saponin production: in vitro cultures, elicitation, and metabolic engineering. Appl Biochem Biotechnol 164: 220-237. DOI: 10.1007/s12010-0109129-3.

Liu J, Xu Y, Liang L, Wei J. 2015. Molecular cloning, characterization and expression analysis of the gene encoding 1-deoxy-D-xylulose 5- phosphate reductoisomerase from Aquilaria sinensis (Lour.) Gilg. J Genet 94 (2): 239-249. DOI: 10.1007/s12041-015-0521-1.

Matatula J, Erny POE, Satyawan P, Ronggo S. 2019. Spatial distribution of salinity, mud thickness and slope along mangrove ecosystem of the coast of Kupang District, East Nusa Tenggara, Indonesia. Biodiversitas 20 (6): 1624-1632. DOI: 10.13057/biodiv/d200619.

Mulyaningsih T, Yamada I. 2007. Notes on some species of agarwood in Nusa Tenggara, Celebes and West Papua. In: Natural Resource Management and Socio-Economic Transformation under the Decentralization in Indonesia: Toward Sulawesi Area Studies. CSEAS, Kyoto University, Kyoto.

Murtaip. 2010. Agarwood compound induction through combined chemical compounds and acremonium. [Thesis]. Institut Pertanian Bogor, Bogor. [Indonesian]

Naef R. 2011. The volatile and semi-volatile constituents of agarwood, the infected heartwood of Aquilaria species: A review. Flavour Fragr J 26: 73-89. DOI: 10.1002/ffj.2034.

$\mathrm{Ng}$ LT, Chang YS, Azizil AK. 1997. A review on agar (Gaharu) production Aquilaria species. J Trop For Prod 2: 272-285

Nobuchi T, Siripatanadilok S. 1991. Preliminary observation of Aquilaria crassna wood associated with the formation of aloe wood. Bull Kyoto Univ 63: 226-235

Nor MA, Husni SS, Mailina J, Sahrim L, Majid JA, Mohd Z, Science F. 2015. Classification of resin content. J Trop For Sci 25 (2): 213-219.

Novriyanti E. 2008. The role of Extractive Substance in Agarwood formation in Aquilaria crassna Pierre ex Lecomte and Aquilaria microcarpa Baill. [Thesis]. Institut Pertanian Bogor, Bogor. [Indonesian]

Okudera Y, Ito M. 2009. Production of agarwood fragrant constituents in Aquilaria calli and cell suspension cultures. Plant Biotechnol 26: $307-$ 315. DOI: 10.5511/plantbiotechnology.26.307.

Pojanagaroon S, Kaewrak. 2002. Mechanical methods to stimulate aloe wood formation in Aquliaria crassna (Kritsana) trees. [Abstract]. Acta Horticul 676: 161-166. DOI: 10.17660/ActaHortic.2005.676.20.

Putri AL, Gayuh R, Juliarni. 2008. Induksi pembentukan senyawa terpenoid pada pohon gaharu (Aquilaria crassna) dengan Acremonium sp. dan metal jasmonat. Enviagro 2: 23-28.

Qi SY, He ML, Lin LD, Zhang CH, Hu LJ, Zhang HZ. 2005. Production of 2-(2-phenylethyl) chromones in cell suspension cultures of Aquilaria sinensis. Plant Cell Tiss Organ Cult 83: 217-221. DOI: 10.1007/s11240-005-5479-x.

Qi SY. 1995. Aquilaria species: In vitro culture and production of eaglewood (agarwood). In: Bajaj YPS (eds.) Biotechnology in Agriculture and Forestry 33. Springer, New York. DOI: 10.1007/9783-662-08612-4_3.

Rahayu, Erdi, Fauziah. 2009. The Effectivity of Ethylene in inducing the production of Terpenoid compound in Agarwood Tree (Aquilaria microcarpa). National Seminar I "Menuju Produksi Gaharu Secara Lestari di Indonesia". IPB International Convention Center, Bogor, 12 November 2009. [Indonesian]

Rahayu G. 2009. The status of Research and Agarwood Development in Indonesia. National Seminar I "Menuju Produksi Gaharu Secara Lestari di Indonesia". IPB International Convention Center, Bogor, 12 November 2009. [Indonesian]

Rao KR, Dayal R. 1992. The secondary xylem of Aquilaria agallocha (Thymelaeaceae) and the formation of 'Agar'. IAWA J 13: 163-172. DOI: 10.1163/22941932-90001264

Rindiyastuti R, Yulistyarini T, Darmayanti AS. 2019. Population and ecological study of agarwood producing tree (Gyrinops verstegii) in Manggarai Distrik, Flores Island, Indonesia. Biodiversitas 20: 11801191. DOI: $10.13057 /$ biodiv/d200434.

Siburian RHS, Ulfah JS, Iskandar S, Erdy S, Imam W. 2013. Identification of anatomical characteristics of Aquilaria microcarpa in its interaction with Fusarium solani. Biotropia 20 (2): 104-111. DOI: $10.11598 /$ btb.2013.20.24

Sumarna. 2002. Budidaya Gaharu, Seri Agribisnis. Penebar Swadaya, Jakarta. [Indonesian]

Thanh LV, Tran VD, Nguyen HS, Tamotsu S, Osamu K. 2015. Impacts of biological, chemical and mechanical treatments on sesquiterpene content in stems of planted Aquilaria crassna trees. Agro Syst 89 (6): 973-981. DOI: 10.1007/s 10457-015-9829-3

Walker D Jr, Taylor RW, Mulrooney RP. 1997. Diagnosing Field Crop Problems. [Retrieved on 2013 Sep 26]. http://ag.udel.edu/extension.

Winarsih. 2014. Effect of stressing to agarwood producing at gaharu (Aquilaria malaccensis Lamk) tree. Student Online Journal of Riau Agriculture Faculty 1 (1). [Indonesian] 
Wong YF, Chin ST, Perlmutter P, Marriott PJ. 2015. Evaluation of comprehensive two-dimensional gas chromatography with accurate mass time-of-flight mass spectrometry for the metabolic profiling of plant-fungus interaction in Aquilaria malaccensis. J Chromatogr A 1387: 104-115. DOI: 10.1016/j.chroma.2015.01.096
Wulandari E. 2009. The effectivity of Acremonium sp. and Fusarium sp. as the double inductor on the formation of agarwood in Aquilaria microcarpa Tree [Thesis]. IPB, Bogor. [Indonesian] 